\title{
Ganglion Cells in the Turtle Retina Contain the Neuropeptide LANT-6
}

\author{
William D. Eldred, ${ }^{1}$ Tomoki Isayama, ${ }^{1}$ Anton Reiner, ${ }^{2}$ and Robert Carraway ${ }^{3}$ \\ 'Department of Biology, Boston University, Boston, Massachusetts, 02215, 2Department of Anatomy and Cell Biology, \\ University of Michigan, Ann Arbor, Michigan 48109, and ${ }^{3}$ Department of Physiology, University of Massachusetts Medical \\ School, Worcester, Massachusetts 01605
}

This study investigated the presence of the neurotensinrelated hexapeptide, LANT-6, in retinal ganglion cells and their central projections in the turtle Pseudemys scripta elegans. Immunocytochemical techniques demonstrated that many of the cells in the ganglion cell layer of the turtle retina could be labeled with an antiserum specific for LANT-6. Radioimmunoassay and chromatographic analysis confirmed the presence of LANT-6-related peptides in retina, as well as brain. Several molecular forms of LANT-6 were observed, some larger than LANT-6. Characterization of the cells labeled in the ganglion cell layer in terms of their cell body size and their dendritic arborization patterns revealed that at least 6 specific LANT-6-positive cell types were present in the ganglion cell layer. Morphologically, the LANT-6-positive cells strongly resembled turtle ganglion cells, as previously described. In addition, two other lines of evidence supported this interpretation. First, double-label studies were performed in which retinal ganglion cells projecting to the tectum were retrogradely labeled by HRP injected into the tectum (using a cobalt chloride color-modified DAB reaction product) and immunocytochemically labeled with DAB using the antiserum against LANT-6. These double-label studies revealed that many of the LANT-6-positive cells in the ganglion cell layer in the portion of the retina labeled retrogradely by the HRP injection did project to the tectum. Within the retrogradely labeled portion of the retina, LANT-6-positive cells that were not labeled retrogradely, as well as neurons labeled retrogradely that did not contain LANT-6 were also observed. Second, the central projections of LANT-6-positive cells of the ganglion cell layer were examined by studying the effects of monocular enucleation on the distribution of LANT-6-positive fibers in the central projection targets of the turtle retina. Two to 8 weeks after enucleation, a substantial reduction in LANT-6-positive fibers was observed in all retinal target areas contralateral to the enucleated eye. Radioimmunoassay and chromatographic studies confirmed the presence of LANT-6-related peptides in the turtle brain and corroborated the reduction of LANT-6 observed in the contralateral tectum following monocular enucleation.

Previous studies have demonstrated that LANT-6-related material is present in cells of the ganglion cell layer in a

Received Jan. 12, 1987; revised June 22, 1987; accepted July 7, 1987.

This research was supported by EY04785 to W.D.E., NS19620 to A.R., and AM19428 to R.E.C. We wish to thank Felicitas Eldred for valuable technical assistance and help with preparation of the manuscript.

Correspondence should be addressed to Dr. William D. Eldred, Department of Biology, Boston University, 2 Cummington Strect, Boston, MA 02215.

Copyright (C) 1988 Society for Neuroscience $0270-6474 / 88 / 010119-14 \$ 02.00 / 0$ variety of vertebrates. The present results indicate that LANT-6 is in ganglion cells and that it may play a role in neurotransmission between retinal ganglion cells and their central target areas.

A wide variety of neuropeptides and neurotransmitters have been identified in cells of the vertebrate retina (Ehinger, 1985). With few exceptions, these neuroactive substances have been localized within amacrine cells. Only in the case of substance $P$ in the rabbit retina (Johnson et al., 1986) has a neuropeptide been unequivocally localized within ganglion cells in normal adult retinas, although several peptides have been observed in retinal ganglion cells in developing frog retina and in optic nerve fibers following optic nerve ligation in adult frogs (Kuljis et al., 1984; Kuljis and Karten, 1985b).

Using an antiserum against a recently discovered neurotensinrelated hexapeptide termed LANT-6 (H-Lys-Asn-Pro-Tyr-IleLeu-OH), which was first isolated from the chicken small intestine (Carraway and Ferris, 1983), labeled cells were recently reported in the ganglion cell layer (GCL) of the retina of several vertebrate species (Li et al., 1984; Eldred et al., 1987). Structurally, LANT-6 resembles the C-terminal, biologically active portion of neurotensin (NT). NT is a 13 amino acid peptide with a broad spectrum of action, including effects on dopamine metabolism, temperature regulation, and pain perception, as well as gastrointestinal motility and secretion (for review, Nemeroff and Prange, 1982; Kitabgi et al., 1984). A specific function for LANT- 6 has not been established, although actions similar to those of NT, such as the modulation of gastrointestinal motility, have been suggested since LANT -6 has been shown to bind with low affinity to NT receptors on rat brain synaptic membranes (Kitabgi et al., 1984). Carraway and Ferris (1983), however, have found that LANT-6 possesses biological activities different from those of NT, including a hypertensive response upon administration as opposed to a hypotensive response associated with NT. LANT-6 and a similar neuropeptide first discovered in mammals, neuromedin $\mathrm{N}$, have actions in some of these systems which are not identical to those for NT (Kitabgi et al., 1984; Minamino et al., 1984; Kalivas and Richardson-Carlson, 1985). In the bird, LANT-6 and NT are distributed in a similar, but not identical, manner in different types of tissues and have been localized in both nerve and endocrine cells. Within the CNS, subcellular fractionation shows LANT-6 to be associated with synaptosomes and vesicles (Carraway et al., 1983). This information suggests roles for LANT-6 and neuromedin $\mathrm{N}$ as modulators or transmitters in the CNS.

In the present study, we have used an antiserum directed against LANT-6 (Carraway and Ferris, 1983) to study cells of 


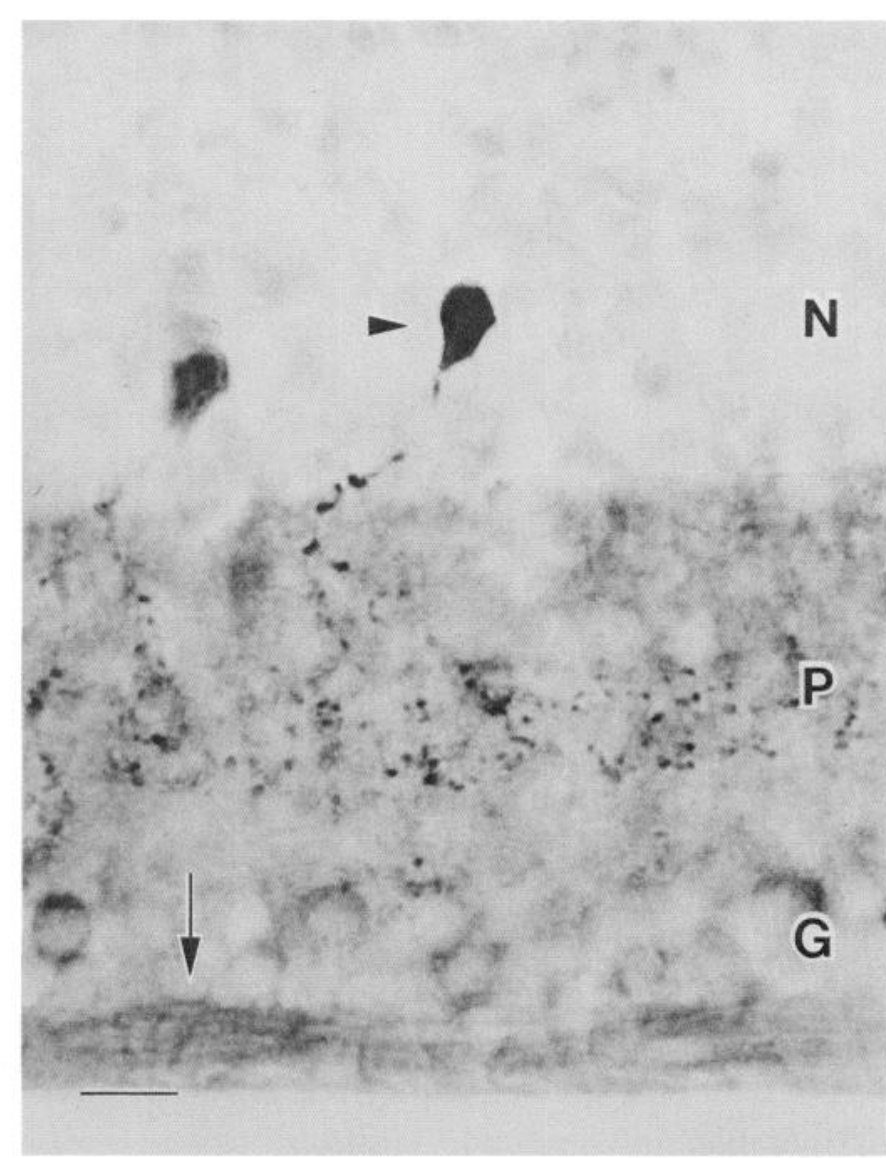

Figure 1. Small amacrine cell type with LANT-6-like immunoreactivity (arrowhead). Many darkly stained beaded processes from these neurons are apparent in the inner plexiform layer. The arrow indicates labeled ganglion cell axons in the nerve fiber layer. Scale bar, $10 \mu \mathrm{m}$.

the GCL in turtles and establish, by using several different approaches, that many retinal ganglion cells in turtles contain LANT-6-like immunoreactivity (LLI) and have LLI-positive projections to the CNS.

\section{Materials and Methods}

Red-eared turtles (Pseudemys scripta elegans) were used in the present studies. Turtles were housed at $30^{\circ} \mathrm{C}$ with a $12 \mathrm{hr}-12 \mathrm{hr}$ light-dark cycle. In previous studies ( $\mathrm{Li}$ et al., 1984; Eldred et al., 1987), an antiserum specific for the NT-related hexapeptide LANT-6 was used to demonstrate immunocytochemically the presence of numerous LLI-positive cells in the GCL of the retina of the red-eared turtle. In the present study, these cells were characterized in greater detail according to their cell sizes and dendritic morphology in order to determine whether these cells were retinal ganglion cells. The precise identity and amount of the LLI in the turtle retina was determined by gel chromatography, highpressure liquid chromatography (HPLC), and radioimmunoassay (RIA). Two lines of investigation were used to further establish that the LLIpositive cells of the turtle GCL were ganglion cells and that they had LLI-positive projections to central retinal projection targets: (1) LLIpositive retinal ganglion cells projecting to the tectum were doublelabeled by combining retrograde HRP labeling techniques with immunocytochemical techniques, and (2) the effect of monocular enucleation on LLI-positive fibers in central retinal target areas was examined using immunocytochemical techniques. The identity of the LANT-6-like substance in the CNS was examined using gel chromatography and HPLC. In addition, the effects of monocular enucleation on LLI levels in central retinal target areas were measured using RIA.

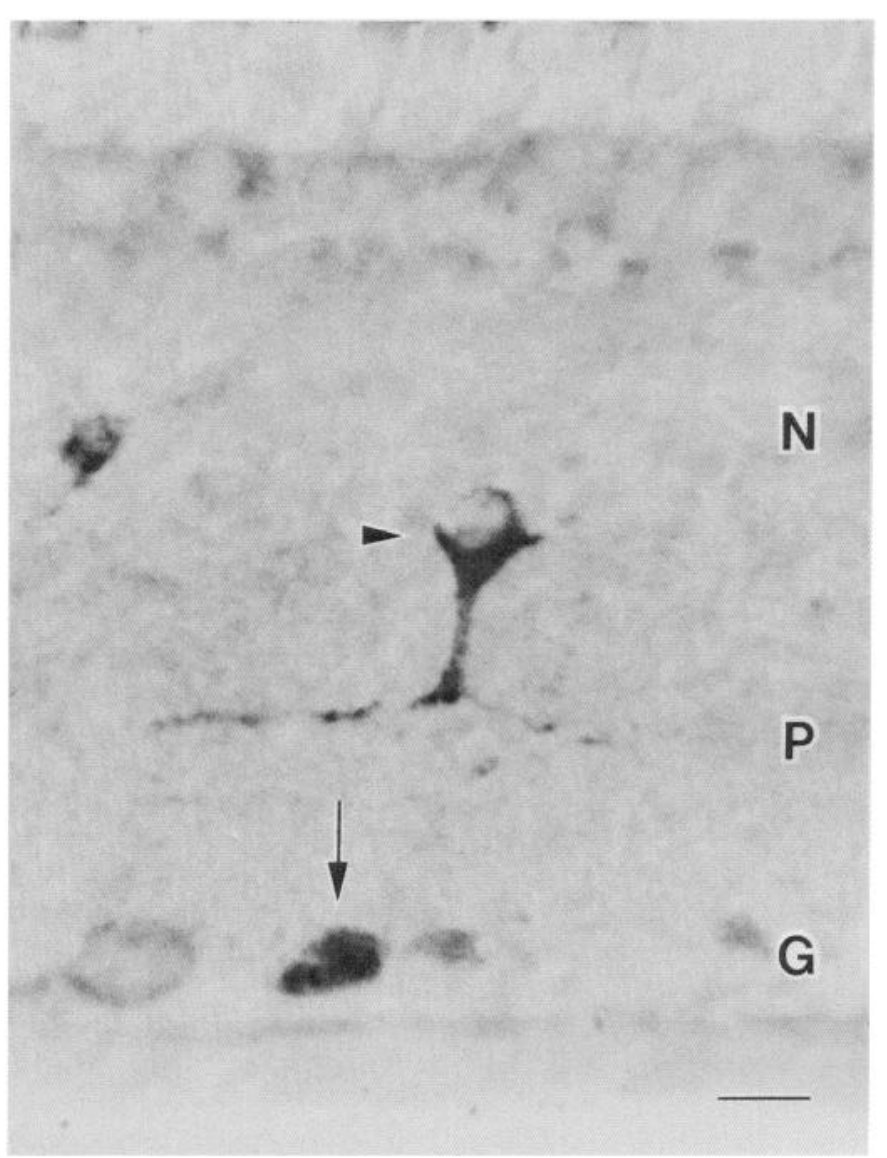

Figure 2. Transverse section of the large amacrine cell type with LANT6-like immunoreactivity (arrowhead). A single primary process gives rise to secondary processes that are lightly labeled and difficult to follow in the inner plexiform layer. The arrow indicates a labeled ganglion cell body. Scale bar, $10 \mu \mathrm{m}$.

\section{Immunocytochemistry}

Retina. Eyes were quickly dissected from turtles that had been given 1 $\mathrm{ml} / \mathrm{kg}$ of T-61 euthanasia solution (American Hoechst Corporation), and the anterior chamber and lens were removed. The eye-cup was then fixed by immersion in $4.0 \%$ paraformaldehyde in $0.1 \mathrm{M}$ phosphate buffer at $\mathrm{pH} 7.4$ (PB). Following this fixation of the retina for $30 \mathrm{~min}$ to $6 \mathrm{hr}$, the eye-cup was placed overnight in a solution of $30 \%$ sucrose in PB. The following day, the retina was removed from the eye-cup and sectioned flat on a sliding microtome, or cross sections of the intact eyecup were cut on a cryostat. Flat-mounted sections were cut at a thickness of 50-80 $\mu \mathrm{m}$. Retinal sections were pretreated in $10.0 \%$ normal sheep serum in PB for $30 \mathrm{~min}$. After pretreatment, the sections were immediately transferred into a 1:500 dilution of an anti-LANT-6 antiserum raised in rabbit, TG-22 (Carraway et al., 1983), and incubated overnight with gentle agitation at $4^{\circ} \mathrm{C}$. The primary antiserum and all other antisera used in the present study were diluted with PB containing $0.3 \%$ Triton $\mathrm{X}-100$. Following incubation in the primary antiserum, retinal sections were washed using two 10 min changes of $\mathrm{PB}$, then incubated overnight at $4^{\circ} \mathrm{C}$ in a $1: 100$ dilution of anti-rabbit IgG (raised in sheep). After incubation in the secondary antiserum, sections were washed using two 10 min changes of $\mathrm{PB}$, then incubated overnight at $4^{\circ} \mathrm{C}$ in a $1: 100$ dilution of rabbit peroxidase-antiperoxidase (PAP). Following incubation in PAP, sections were washed in at least two 10 min changes of $P B$. Sections were then transferred to a 3,3-diaminobenzidine tetrahydrochloride (DAB) solution consisting of $0.05 \mathrm{M}$ Tris buffer at $\mathrm{pH} 7.4$ (TB) with $0.34 \mathrm{gm} / 100 \mathrm{ml}$ of imidazole and containing DAB $(25 \mathrm{mg}$ $\mathrm{DAB} / 100 \mathrm{ml}$ ). Retinal sections were preincubated for 20-30 min. After preincubation, $20 \mu \mathrm{l}$ of $30 \%$ hydrogen peroxide $/ 100 \mathrm{ml}$ of DAB solution was added to the solution in which the sections were incubating and the sections were allowed to incubate for an additional 20-30 min. After 


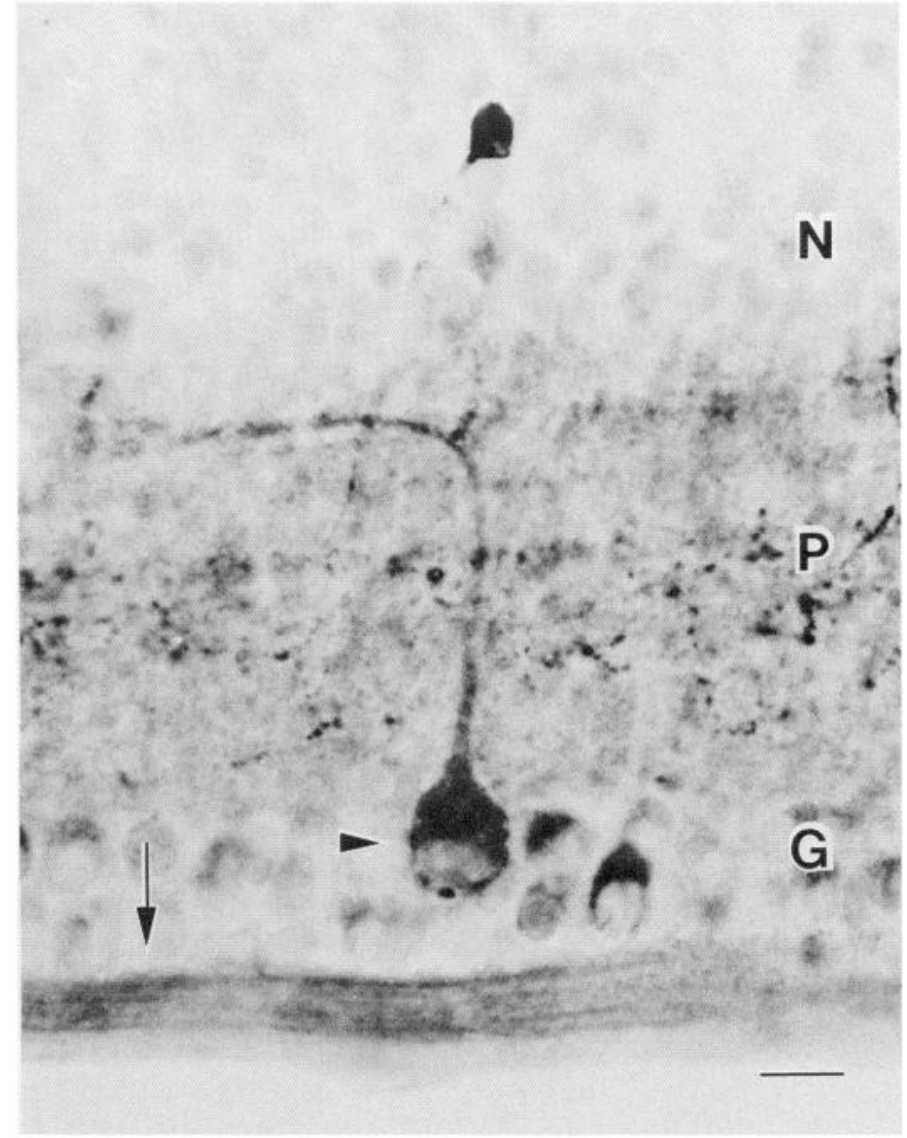

Figure 3. The arrowhead indicates a large labeled monostratified ganglion cell that arborizes in strata 1 of the inner plexiform layer. Many labeled ganglion cell axons are present (arrow) in the nerve fiber layer. Scale bar, $10 \mu \mathrm{m}$.

reacting, the sections were removed from the reaction mixture and washed in 5-6 changes of PB. Sections were then mounted on slides and examined using light microscopy. The specificity of the immunoreactivity was assessed by blocking the LANT-6 antiserum with 10-50 $\mu \mathrm{M}$ synthetic LANT-6.
Brain. The brains of normal as well as monocularly enucleated turtles were examined with the LANT-6 antiserum using immunocytochemical techniques. For the monocular enucleations, turtles were anesthetized using ketamine hydrochloride (Ketaset; $60 \mathrm{mg} / \mathrm{kg}$ ), one eye was removed, and the eye socket was then filled with Gelfoam and the eyelids sewn shut. The brains of monocularly enucleated turtles were examined 2, 4, 6, and 8 weeks after enucleation. Turtles were anesthetized deeply as described above and perfused transcardially with $200 \mathrm{ml}$ of $0.75 \% \mathrm{NaCl}$ in distilled water, followed by $400 \mathrm{ml}$ of $4 \%$ paraformaldehyde in PB. The brains were then removed and postfixed 4-18 hr in $4 \%$ paraformaldehyde in $0.1 \mathrm{~m}$ disodium hydrogen phosphate buffer at $\mathrm{pH} 10.0$. The brains were then stored overnight in $30 \%$ sucrose-PB at $4^{\circ} \mathrm{C}$ and subsequently sectioned frozen at $40 \mu \mathrm{m}$. Brain sections were processed using the LANT-6 antiserum according to immunocytochemical procedures as described previously (Reiner and Carraway, 1985, 1987). These procedures were similar to those described above for processing the retina. The specificity of the immunoreactivity for LANT-6 was assessed by blocking the antiserum with 10-50 $\mu \mathrm{M}$ synthetic LANT-6.

\section{Retrograde labeling}

Turtles were anesthetized using $60 \mathrm{mg} / \mathrm{kg}$ Ketaset. The skull was surgically opened and the tectum exposed. A fine needle was used to lacerate the surface of the tectum to expose and damage as many ganglion cell fibers in this region as possible. An HRP implant, consisting of approximately $2.0-3.0 \mu \mathrm{g}$ of HRP in $1.0-2.0 \mu \mathrm{l}$ of PB, was then placed on the damaged tectum and the wound was sealed using Gelfoam and sutures. After a 1 week survival period, which proved to be optimal for retrograde transport from the tectum to retinal ganglion cells, animals were sacrificed using T-61 euthanasia solution. The eye contralateral to the injected tectum was removed, fixed, and sectioned as described previously. After the eye was removed, these turtles were perfused and the brains removed and sectioned as described previously. The brain sections through the tectum were processed using DAB as described above to confirm the location of the HRP injection site. The retinal sections from these turtles were rinsed in TB and then incubated in a $0.5 \%$ solution of cobalt chloride in TB for $5-10 \mathrm{~min}$. The tissue was then washed in TB 3-4 times again and then processed using DAB as described previously. The cobalt chloride incubation preceding the DAB reaction was used to yield a blue HRP reaction product. Following this cobalt chloride color-modified DAB reaction, the retinal sections were processed according to immunocytochemical techniques for the presence of LLI using the PAP technique and a standard DAB reaction. In tissue processed this way, blue reaction product from retrogradely transported HRP could be differentiated from the brown reaction product resulting from immunocytochemical staining procedures.

\section{LANT-6 POSITIVE GANGLION CELLS}

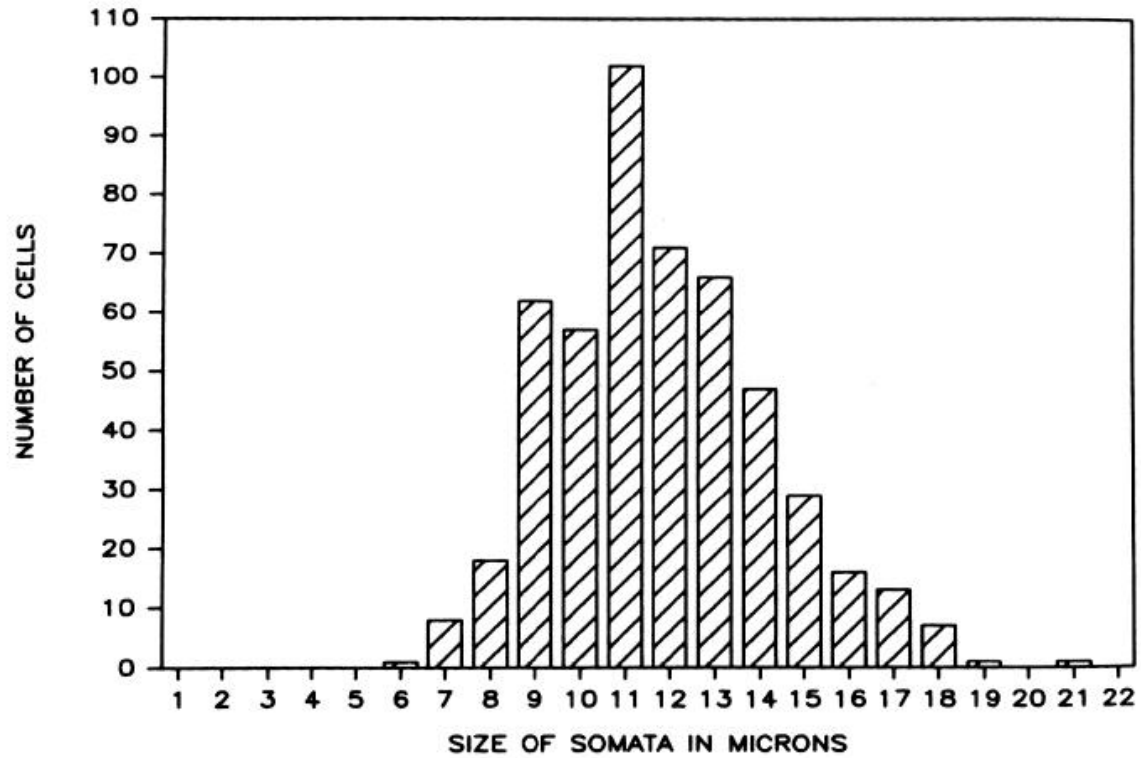

Figure 4. Size range of ganglion cell bodies with LANT-6-like immunoreactivity. 

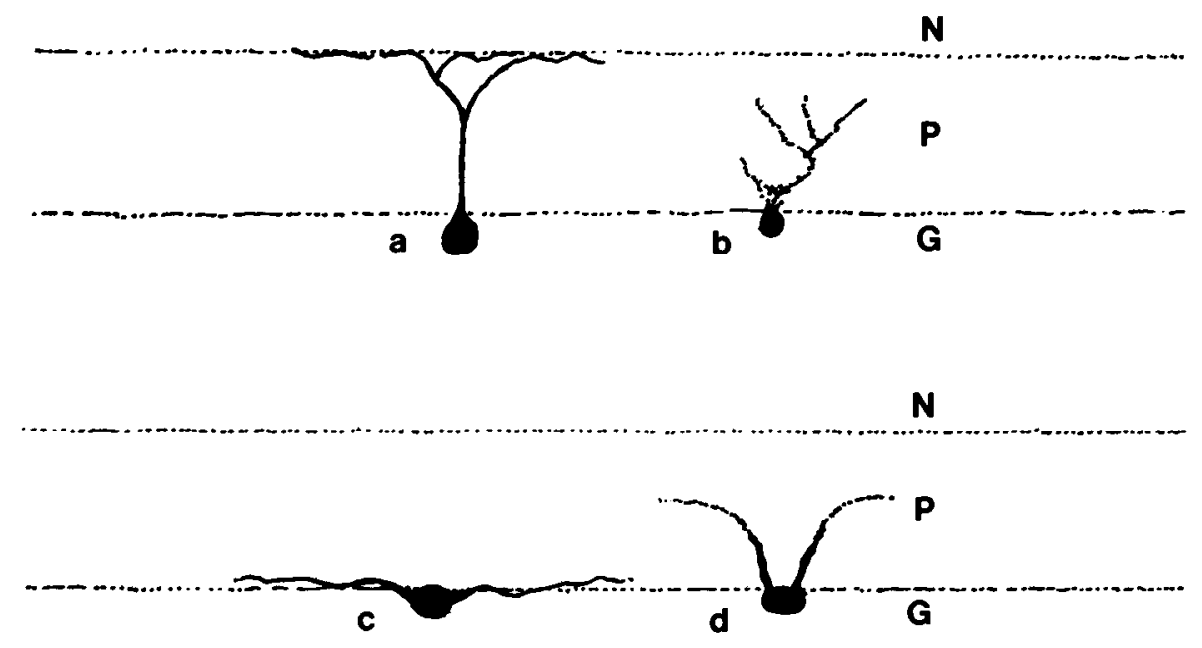

Figure 5. Schematic representation of 6 ganglion cell types that contain LANT6-like immunoreactivity. The different cell types were found with the following size ranges: $a, 11-18 \mu \mathrm{m} ; b, 7-12 \mu \mathrm{m}$; $c, 12-22 \mu \mathrm{m} ; d, 14-22 \mu \mathrm{m} ; e, 17-20 \mu \mathrm{m}$; and $f, 8-10 \mu \mathrm{m}$. Scale bar, $20 \mu \mathrm{m}$.

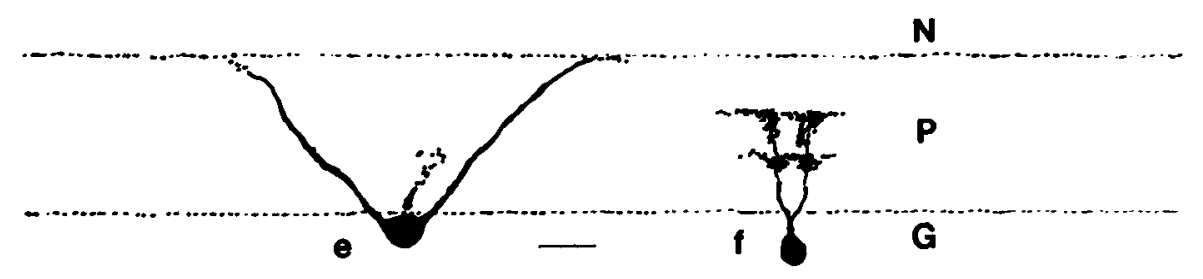

\section{Biochemistry}

Radioimmunoassay. Brain and retinal tissues were dissected free on ice and extracted into $10 \mathrm{vol}$ of $0.1 \mathrm{~N} \mathrm{HCl}$, boiled for $5 \mathrm{~min}$ and lyophilized. The extract was then reconstituted in an assay buffer and subjected to RIA for LANT -6 and NT using previously described procedures. Antiserum $\mathrm{HC}-8$, which is directed towards the biologically active C-terminal octapeptide of NT, was used to measure NT-like immunoreactivity (NLI) (Carraway and Leeman, 1976). Antiserum TG-22, which cross-reacts less than $0.01 \%$ with NT, was used to measure LLI (Carraway et al., 1983). The assays were allowed to come to equilibrium, bound and free radioactivity were separated by addition of dextrancoated charcoal, and bound radioactivity was quantitated using a 16 well gamma-counter. On-line computerized data analysis was performed using a log-logit linearization program (IN/US Service Corp., Fairfield, NJ). Concentrations were measured near the $\mathrm{ED}_{50}$ for each assay and extracts diluted in a near-parallel manner to the standard.

High-pressure liquid chromatography. Chromatography was performed using a dual-pump system (model 204, Waters Associates, Milford, MA) and a column $(3.5 \mathrm{~mm} \times 30 \mathrm{~cm})$ of a $\mu$-Bondapak C-18. The column was equilibrated at $1.5 \mathrm{ml} / \mathrm{min}$ with $10 \mathrm{~mm}$ sodium phosphate, $150 \mathrm{~mm}$ sodium chloride ( $\mathrm{pH} 5.0$ ) and after injection of the sample, a 30 min linear gradient to $30 \%$ acetonitrile was applied, while collecting fractions of $0.75 \mathrm{ml}$.

\section{Gel chromatography}

Gel chromatography was performed on a Sephadex G-25 column $(1.6 \times$ $96 \mathrm{~cm})$ using $0.2 \mathrm{~m}$ acetic acid as an elutent. After the sample $(1-2 \mathrm{ml})$ was applied, $40 \mathrm{ml}$ of effluent was discarded, and fractions of $2.2 \mathrm{ml}$ were collected. Aliquots of some fractions were incubated with $0.5 \mathrm{mg} /$ $\mathrm{ml}$ hog pepsin (Sigma Chemical Co.) in $0.2 \mathrm{M}$ acetic acid (pH 2.5) at $40^{\circ} \mathrm{C}$ for $1 \mathrm{hr}$.

\section{Results}

The immunocytochemical studies of the retina revealed that the LANT-6 antiserum labeled a morphologically heterogeneous population of cells in the GCL and inner nuclear layer (INL) of the turtle retina. Based on their cell size and dendritic mor- phology, a number of specific LLI-positive cell types could be identified, some of which correspond to previously recognized amacrine and ganglion cell types in reptiles. Retrograde labeling in conjunction with immunocytochemistry indicated that LLIpositive cells in the GCL do project to the tectum. Enucleation studies further revealed that the LLI-positive cells of the GCL project to all central targets of the turtle retina. The immunocytochemical findings were confirmed by RIA and the LLI was characterized chromatographically.

\section{Retinal studies}

The LANT-6 antiserum labeled numerous cells in both the GCL as well as in the INL. Among the cells labeled in the INL, 2 of the cell types appeared to correspond to the 2 NT-containing amacrine cell types previously found in the turtle retina (Eldred and Karten, 1983; Eldred and Carraway, 1987) (Figs. 1, 2). Since the anti-NT antiserum used in this previous study did not crossreact with LANT-6, and since the LANT-6 antiserum did not cross-react with NT, it seems likely that LANT-6 and NT cooccur in these amacrine cell types. In addition to these amacrine cells, a number of other LLI-positive cells were observed in the INL that did not correspond to any previously identified amacrine cell types of the turtle retina. Many of these cells were large with a rounded cell body situated at the first tier of cell bodies in the INL. In some cases, these cells were observed to give rise to processes that ramified in the outer lamina of the inner plexiform layer (IPL). Based on their size and shape, many of these cells thus appeared to be LLI-positive displaced ganglion cells.

Within the GCL, at least 10-15\% of the cells appeared to be labeled by the LANT-6 antiserum (Fig. 3). The labeled cells ranged in diameter from 6 to $22 \mu \mathrm{m}$, with the majority of the 


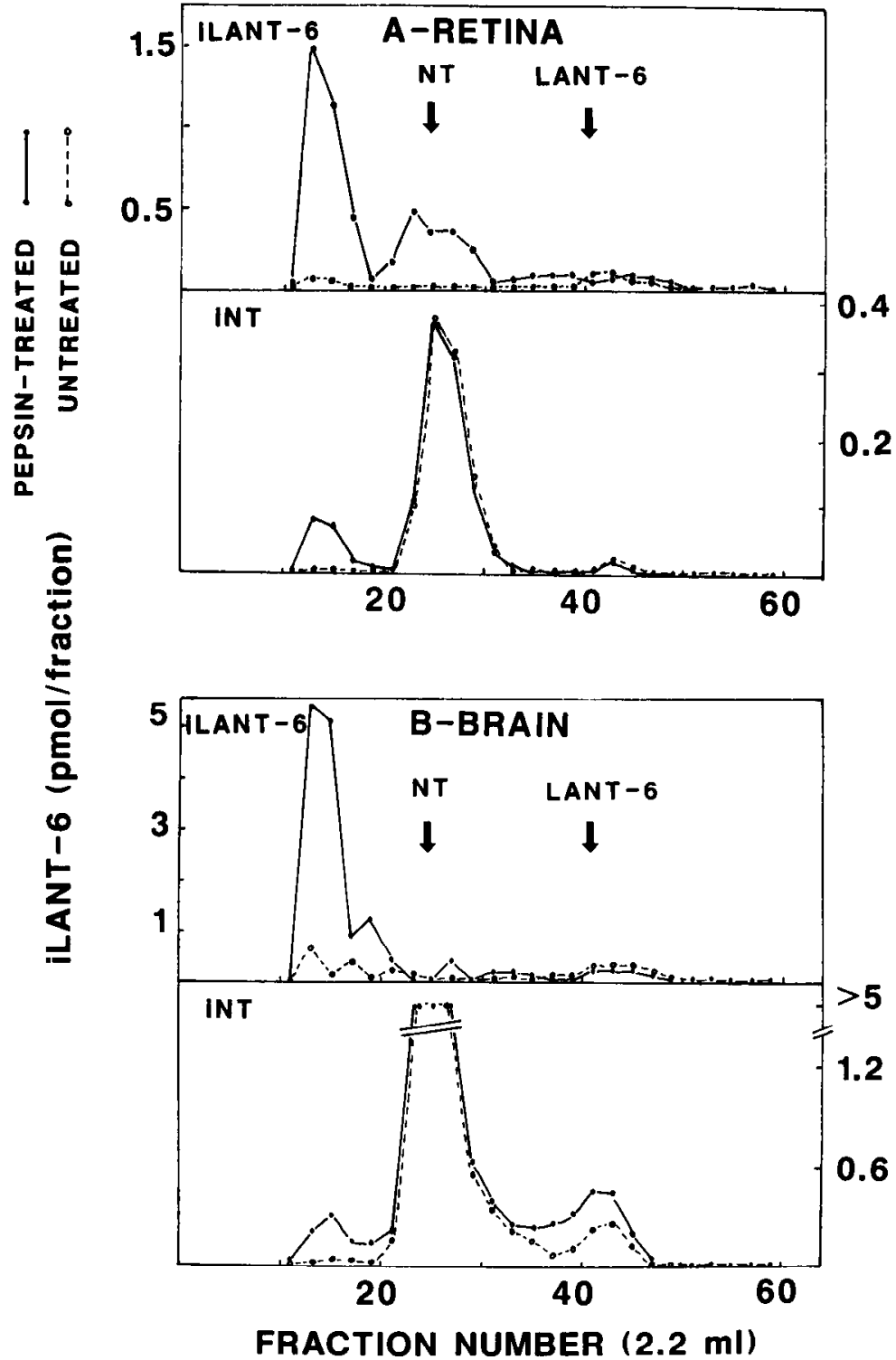

Figure 6. Gel chromatography of acid extracts of turtle retina $(A)$ and turtle brain $(B)$ on Sephadex G-25. See Materials and Methods for details. Measurements of iLANT-6 and iNT are given for untreated elutes, as well as elutes treated with pepsin. Note the large increases in iLANT-6 upon pepsin treatment of the voided proteins. cells being between $8-14 \mu \mathrm{m}$ in size (Fig. 4). Labeling in the majority of LLI-positive cells in the GCL was confined to a thin rim of cytoplasm surrounding the nuclcus. Although most labeled cells in the GCL did not show prominent dendritic labeling, sufficient labeling was observed in many to characterize their branching patterns in the IPL. In cross-sectioned retina, 6 distinct cell types were recognized in the GCL, 4 monostratified cell types, 1 bistratified cell type, and 1 cell type with diffusely stratified dendrites (Fig. 5). These 6 cell types do not necessarily represent an exhaustive classification of the LLI-positive cell types in the turtle GCL since additional LLI-positive cell types, whose poorly labeled dendrites precluded their classification, may also have been present.

\section{Biochemistry}

RIA of $0.1 \mathrm{~N} \mathrm{HCl}$ extracts of turtle retina indicated that they contained even more LLI $(141 \pm 21 \mathrm{pmol} / \mathrm{gm}, n=4)$ than NLI (11 $\pm 2 \mathrm{pmol} / \mathrm{gm}, n=4)$. These results appear to be consistent with the immunocytochemical findings that demonstrated a more extensive staining for LLI than NLI. RIAs of extracts of turtle brain indicated the presence of $183 \pm 19 \mathrm{pmol} / \mathrm{g}(n=4)$ LLI and $142 \pm 19 \mathrm{pmol} / \mathrm{g}(n=4) \mathrm{NLI}$.

When extracts of turtle retina and brain were chromatographed on Sephadex G-25, the profiles of the immunoreactivity shown in Figure 6, $A$ and $B$, respectively, were obtained. The upper panel for each figure depicts results for LLI, while the lower panel gives profiles for NLI. For both tissue extracts, a major peak of NLI was found to elute at the position for chicken NT (fractions 23-28). In contrast, LLI eluted primarily in the void volume of the column, with less than $10 \%$ of the applied activity eluting at the position of synthetic LANT-6 (fractions 41-45).

In order to test whether the voided material represented large molecular forms of LANT-6, it was treated with pepsin, an enzyme that has been shown to mimic processing of precursors in the NT-family. As seen in the upper panels of Figure $6, A$ and $B$, LLI activity was increased more than 10 -fold by this treatment, suggesting that pepsin liberated additional LANT-6- 
Figure 7. Profiles of iLANT-6 obtained during HPLC of synthetic LANT$6(A)$, pepsin-treated retinal proteins $(B)$, and pepsin-treated brain proteins $(C)$. See Materials and Methods for details. The treated proteins were from Figure 6, fractions 12-20. Arrows mark the elution position for native and synthetic LANT-6.

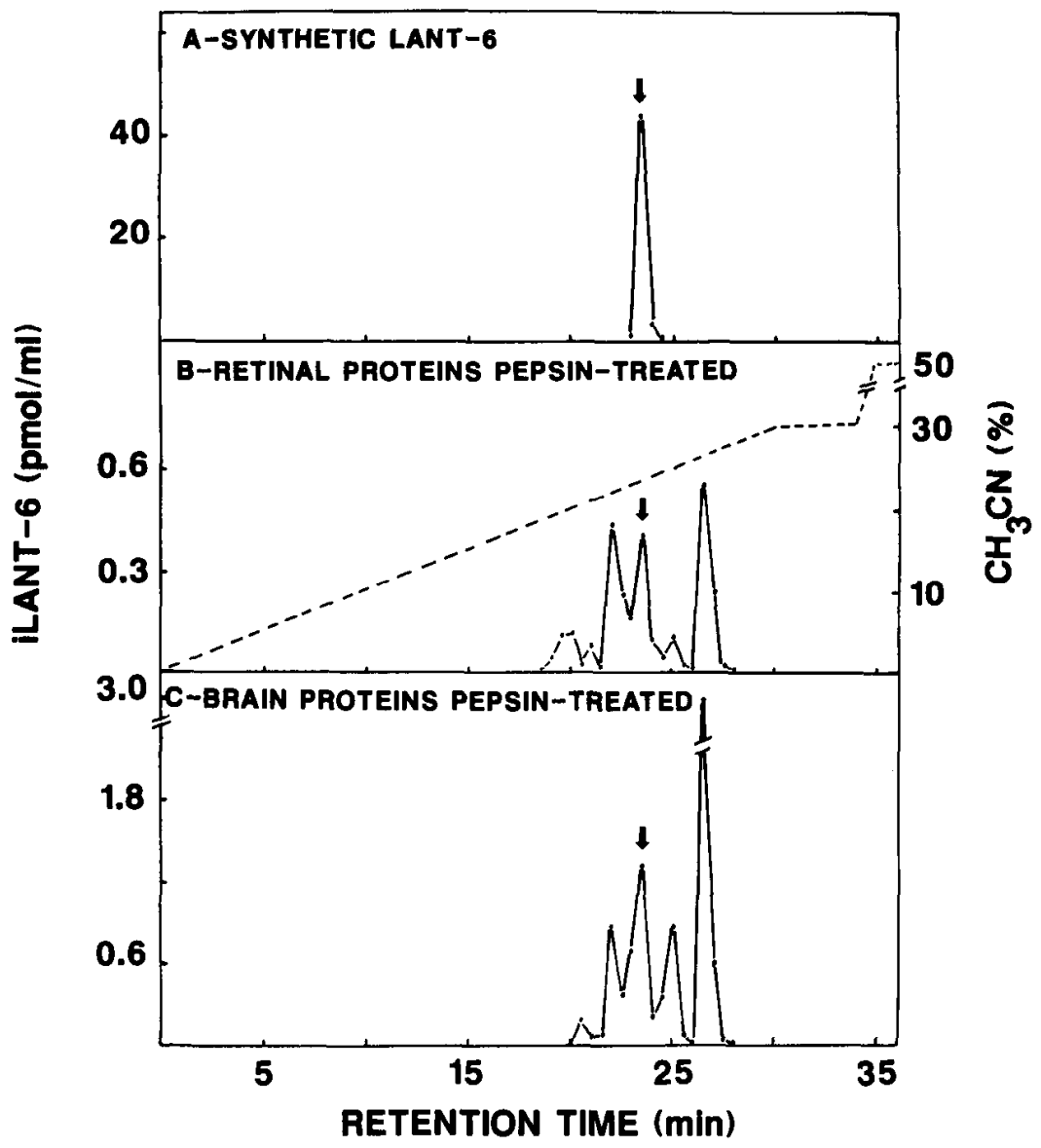

related peptides from these proteins. Although some additional NLI was also formed by pepsin treatment, most of the NLI was present as the fully processed peptide.

To examine the nature of the LANT-6-related peptides generated by pepsin treatment, samples were subjected to HPLC on $\mu$-Bondapak C-18 (Fig. 7, $A-C$ ). Although several forms of LLI were found, ca. $25 \%$ of the total activity liberated by pepsin coeluted with synthetic LANT-6 (retention time, 23.5 min). The 3 other major peaks observed could represent isohormone variants or extended forms of LANT-6.

\section{Retrograde labeling-immunocytochemical studies}

Successful injections of HRP were made in several turtles, as judged by the presence of labeled fibers within the optic tectum and tract of the brain (Fig. 8). Since the retinotectal projection in turtles is topographically organized, retrogradely labeled ganglion cells in the contralateral retina were restricted to that portion of the retina projecting to the HRP-injected portion of the tectum. Within the labeled portion of the retina, many of the cells of the GCL were retrogradely labeled (Fig. 9). Cells in the GCL throughout the retina, in double-labeled retinal tissue (as in the single-labeled retinal tissue) also contained LLI. Examination of the double-labeled tissue revealed that many of the retrogradely labeled neurons (containing a blue $\mathrm{DAB}$ reaction product) also contained a brown DAB reaction product, indicating that these retrogradely labeled cells were also LLI positive (Fig. 10). Double-labeled neurons did appear to represent a heterogeneous population of ganglion cells in terms of size. There were also a number of cells that were not double labeled and contained only LLI.

\section{CNS and enucleation studies}

By both RIA and immunocytochemistry, LLI-related material could be demonstrated in the turtle brain, confirming an earlier study (Reiner and Carraway, 1985). As shown in Figures 11 and 12, LLI-positive labeling was abundant and widespread within the diencephalon and mesencephalon of turtle. The present descriptions deal only with the presence of LLI in retinal recipient areas. LLI-positive labeling was prominent in the optic chiasm and optic tract, and axons of the basal optic root were particularly heavily labeled. LLI-positive fibers and terminals were also observed within all central target areas of the turtle retina. Within the diencephalon, LLI-positive fibers were observed in the neuropil lateral to the dorsal and ventral geniculate nuclei (Fig. 13b). A branch of LLI-positive fibers was also observed to separate from the optic chiasm at rostral diencephalic levels and enter the adjacent portions of the hypothalamus. Labeled axons were observed in the basal optic root throughout its entire extent and LLI-positive fibers were abundant in the nucleus of the basal optic root (Fig. 14b). Within the mesencephalon, LLIpositive fibers were prominent in the area pretectalis, in the region overlying and lateral to the nucleus lentiformis mesencephali and in the retinorecipient layers of the superficial tectum (Fig. 15b). Within the tectum, labeled terminals were most abundant in layers 9-11 and 13 of Ramon (1896). In layers 9-11, the labeling had a diffuse appearance, presumably because the LLI-positive labeling was localized to numerous small retinal terminals. In addition, a sparse network of larger LLI-positive fibers and terminals was observed in layers 9-11. Particularly prominent, discrete bundles of LLI-positive fibers were ob- 


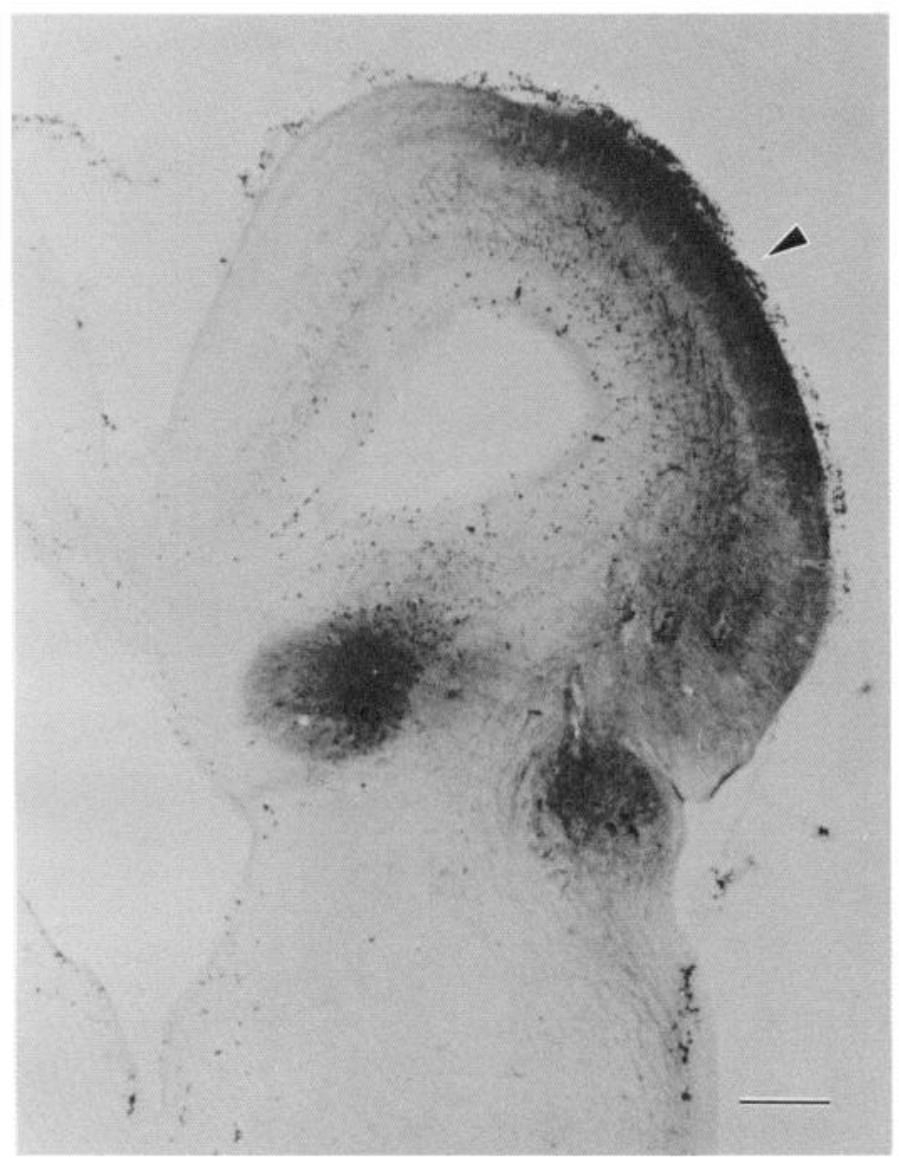

Figure 8. Arrowhead indicates the site where HRP pellet was applied to the optic tectum. Many labeled axons are visible in the optic tract. Scale bar, $500 \mu \mathrm{m}$.

served in the dorsal portions of the neuropil lateral to the dorsal lateral geniculate nucleus at its rostral levels and in the area pretectalis (Fig. 16). Prominent, discrete bundles, similar in appearance to the LLI-positive bundles described here, have been previously observed in studies of the central projections of the retina in turtles (Bass and Northcutt, 1981).

In all turtles with monocular enucleations, reductions were observed in the LLI-positive fiber staining in all retinal targets contralateral to the enucleated eye. These effects were evident 2 weeks after enucleation, but the reductions were most clearly discernible in the animals that had been enucleated 4-8 weeks prior to being sacrificed for immunocytochemical processing. LLI-positive fiber staining was nearly eliminated or completely eliminated from the contralateral optic tract, the neuropil lateral to the dorsal and ventral geniculate (Fig. 13a), the nucleus of the basal optic root (Fig. 14a), the nucleus lentiformis mesencephali, and the area pretectalis (Fig. 16). LLI-positive fibers were considerably reduced in layers $9-11$ and completely eliminated from layer 13 (Fig. 15a). Within layers 9-11, the diffuse labeling was nearly eliminated, while the sparse system of larger fibers was unaffected. Residual LLI-positive fibers in the major retinorecipient layer of the tectum may be contained in a LLIpositive afferent system to the tectum that arises from within the brain. In addition, the branch of LLI-positive fibers entering the hypothalamus was eliminated and LLI-positive fibers were completely eradicated from the basal optic root.

Using RIA to measure the effects of monocular enucleation

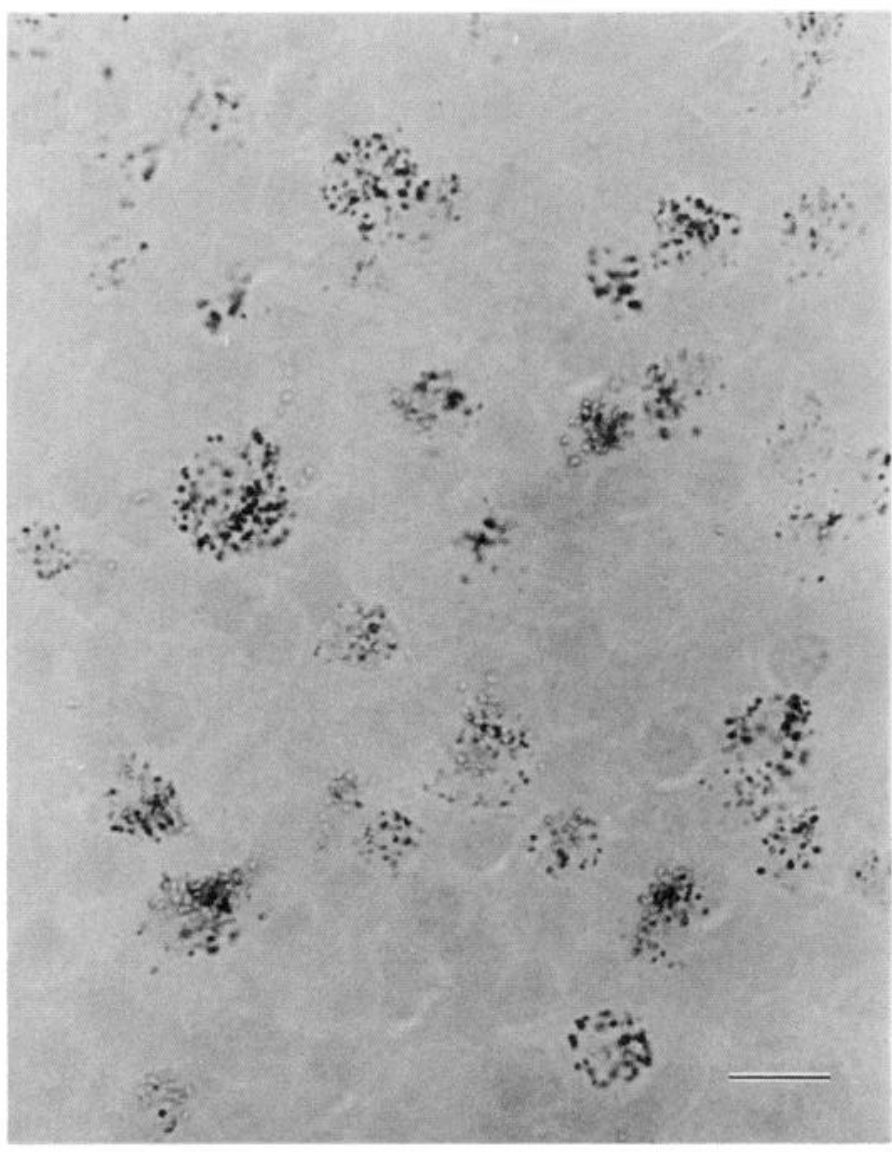

Figure 9. Tangential section through the ganglion cell layer of an animal that received a tectal implant of HRP $7 \mathrm{~d}$ earlier. Many granules of reaction product are visible within the neuronal cytoplasm of retinal ganglion cells. Scale bar, $10 \mu \mathrm{m}$.

on the levels of LLI in the tectum contralateral to the enucleated eye, a clear reduction (about $40 \%$ ) in LLI levels was observed: $154-192 \mathrm{pmol} / \mathrm{gm}$ in the normal tectum and 106-108 pmol/ $\mathrm{gm}$ in the experimental tectum (Table 1). In contrast, there was no evident change in the levels of NT in the tectum following enucleation: $94-95 \mathrm{pmol} / \mathrm{gm}$ in the normal and $80-129 \mathrm{pmol} /$ $\mathrm{gm}$ in the enucleated tectum.

\section{Discussion}

The present results indicate that LLI-positive neurons are present in the GCL of the turtle retina. Several lines of evidence indicate clearly that the majority of these LLI-positive cells are retinal ganglion cells and have LLI-positive projections to the CNS: (1) several specific morphologically distinct types of LLIpositive cell types were observed in the turtle GCL, some of which appear to correspond to retinal ganglion cell types identified in previous studies on reptiles (Ramon y Cajal, 1933; Reiner, 1981; Kolb, 1982); (2) LLI-positive cells in the GCL could be labeled retrogradely by HRP injected into the optic tectum; and (3) enucleation resulted in a dramatic reduction in the LLI-positive fibers present in all central projection targets of the turtle retina.

\section{Anatomical correlations}

Among the LLI-positive cell types observed in the present study that correspond to ganglion cell types identified by previous 


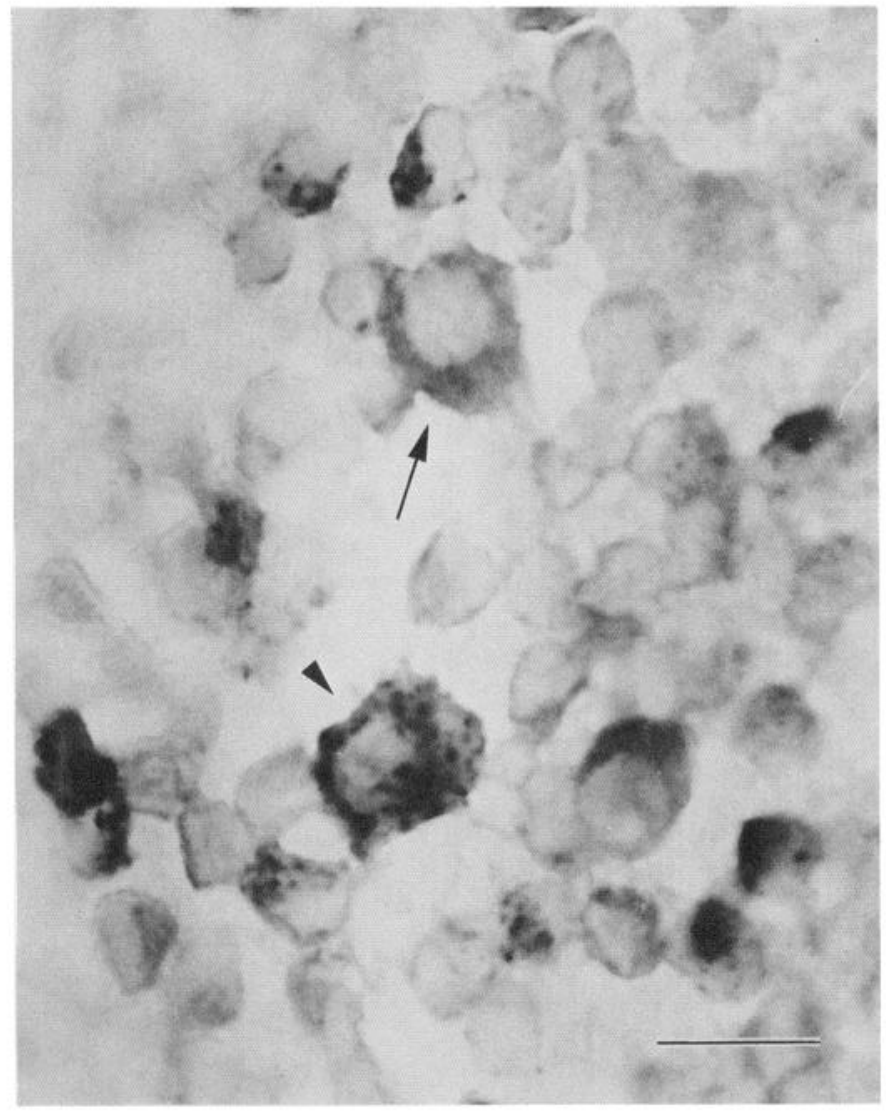

Figure 10. Section taken through the ganglion cell layer of the retina of an animal that was double-labeled by combining a tectal implant of HRP with subsequent immunocytochemical labeling for LANT-6-like immunoreactivity. Arrow indicates a large ganglion cell body that has only the diffuse reaction product indicating LANT-6-like immunoreactivity, while arrowhead indicates a ganglion cell with both diffuse reaction product due to LANT-6-like immunoreactivity and granules of retrogradely transported HRP. Scale bar, $10 \mu \mathrm{m}$.

investigators are displaced ganglion cells (Reiner, 1981; Kolb, 1982) and a population of giant ganglion cells with monostratified dendrites in the outer sublamina of the IPL (Fig. 4). These latter cells correlate with cell type B of Reiner (1981) in his studies of neurons that project to the accessory optic nuclei and to cell type I which Ramon y Cajal observed in Lacerta (1933). This same population of monostratified ganglion cells also closely resembles a similar cell type described as having a sustainedoff physiological response in a study by Weiler and Marchiafava (1981).

Although Kolb (1982) has identified 21 morphologically distinct types of ganglion cells in the retina of Pseudemys, in general, dendritic labeling in this study was insufficient for correlating any of the cell types we found with those of the Kolb study. Such a correlation was additionally hampered by the fact that the Kolb study examined the retinal neurons in flat mounts, while the dendritic arborizations of the neurons in the present study were seen most clearly in cross sections. Many cells in the GCL in turtles, however, did not contain immunocytochemically detectable amounts of LLI and thus LLI is not found in all retinal ganglion cell types. Finally, since approximately $20 \%$ of the cells in the GCL of Pseudemys may not be ganglion cells (Peterson and Ulinski, 1979), not all LLI-positive cells in the GCL may be ganglion cells. Nonetheless, it seems that the ma-

\begin{tabular}{|c|c|c|}
\hline \multirow[b]{2}{*}{ Tissue } & \multicolumn{2}{|c|}{ Immunoreactivity (pmol/gm) } \\
\hline & LANT-6 (TG-22) & $\begin{array}{l}\text { Neurotensin } \\
(\text { HC- } 8)\end{array}$ \\
\hline \multicolumn{3}{|l|}{ Optic tectum } \\
\hline Experimental & $106-108$ & $80-129$ \\
\hline Control & $154-192$ & $94-95$ \\
\hline \multicolumn{3}{|l|}{ Remaining brain } \\
\hline Experimental & $37-72$ & $190-253$ \\
\hline Control & $34-54$ & $115-162$ \\
\hline
\end{tabular}

jority of the LLI-positive cells in the GCL are ganglion cells since our observation that the retina has LLI-positive projections to each central retinal target indicates that one or more of the ganglion cell types projecting to each central target contains LLI.

In the present study, we have succeeded in retrogradely labeling ganglion cells that project to the tectum and contain LANT-6-related material. Although we observed many doublelabeled cells, there were also cells labeled only by the LANT-6 antiserum. This result indicated that we had double-labeled only a restricted percentage of the LLI-positive retinal ganglion cells, which is consistent with our finding that the retina has LLIpositive projections to each central target of the retina. It is possible that a larger percentage of the cells in the GCL in the immunolabeled portion of the retina would have been doublelabeled had we made larger HRP injections and used the ReeseKarnovsky fixative, which preserves the enzymatic activity of HRP better than does paraformaldehyde alone (Adams, 1977; Mesulam, 1981). Our observation that some retrogradely labeled ganglion cells did not contain LLI suggests that many, but not all, retinal ganglion cells projecting to the tectum contain immunocytochemically detectable amounts of LLI.

\section{Biochemical analysis}

The biochemical studies indicated that LLI was present in extracts of turtle retina as well as turtle CNS. Unlike the pigeon and chicken, which store authentic LANT-6, the turtle gave primarily larger molecular forms of LLI, which eluted in the void volume on Sephadex G-25 and exhibited an increased immunoreactivity after treatment with pepsin. Since pepsin has been found to mimic processing for NT-related peptides (Carraway et al., 1986), these results suggest that the larger forms represent precursors to LANT-6-related peptide(s). While in the turtle these larger forms represent more than $90 \%$ of the total LLI, they are almost nonexistent in the pigeon and the chicken, where LLI is stored primarily as the fully processed peptide (Carraway and Reiner, unpublished observations; Reiner and Carraway, 1987). It may be that the larger forms accumulate in turtle because processing to the smaller "active" peptide(s) is slower in this species. Another possibility is that these larger forms are stored and released in order to exert biological actions of their own.

Although the results of the HPLC characterization indicated that pepsin treatment of the large forms liberated material indistinguishable from LANT-6 ( $25 \%$ of total), 3 other peptides were also observed. These substances could represent isohormone variants of LANT-6 or extended LANT-6-related pep- 
a

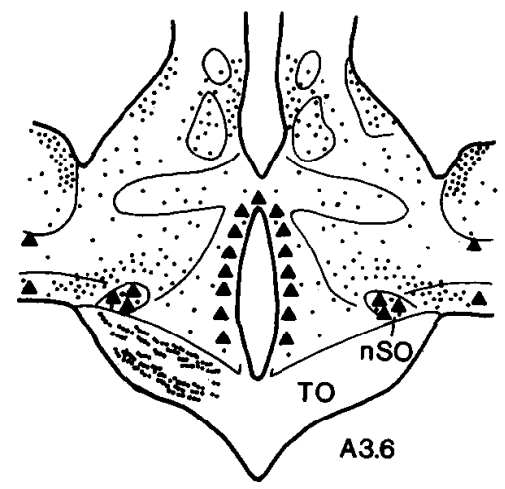

c

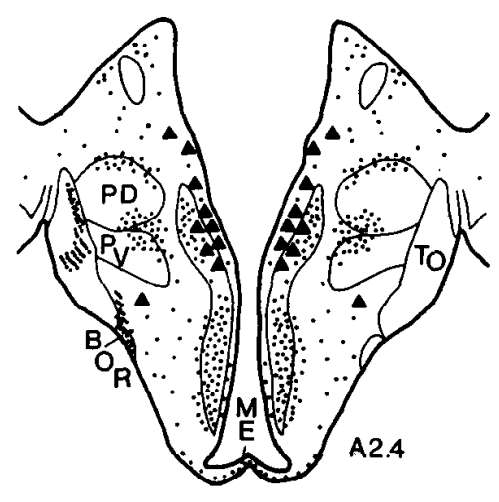

e

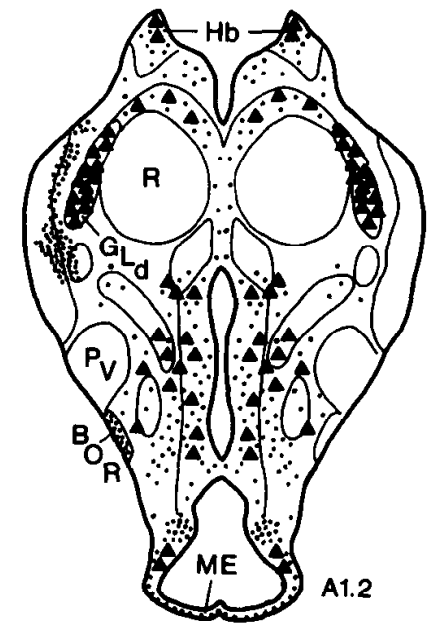

b

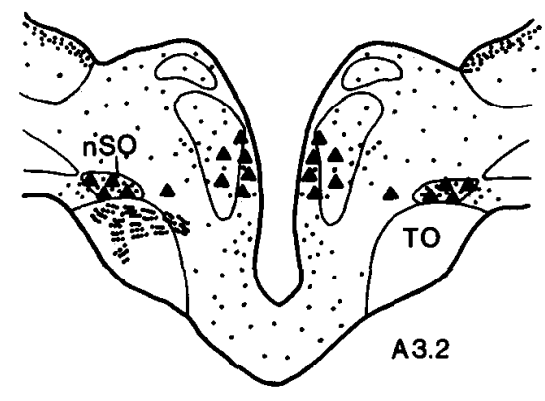

d

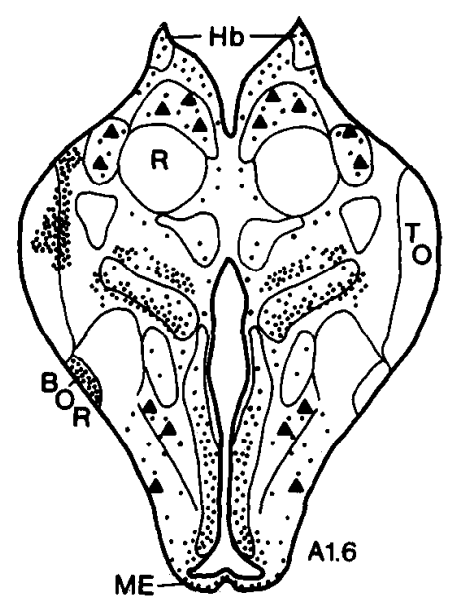

f

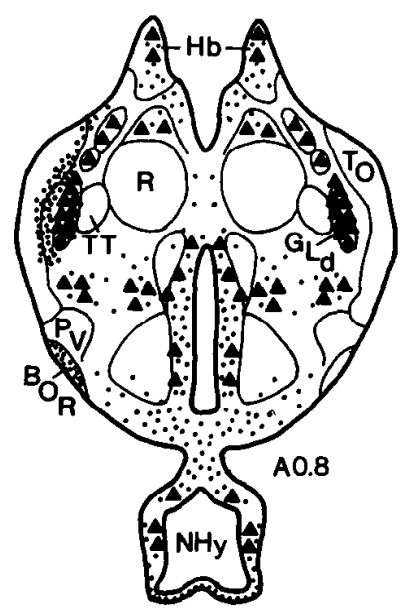

Figure 11. Chartings of a series of sections of turtle brain indicating the localizations of LANT-6-like immunoreactivity. Triangles mark locations of labeled cell bodies, while dots mark labeled nerve fibers and terminals. Left half indicates the location of LANT-6-like immunoreactivity on the control sides of brains. Right half indicates the remaining LANT-6-like immunoreactivity on the experimental side following enucleation of the contralateral eye and a 4-8 week survival period, during which time the ganglion cell axons degenerated. Scale bar, $1 \mathrm{~mm}$. 

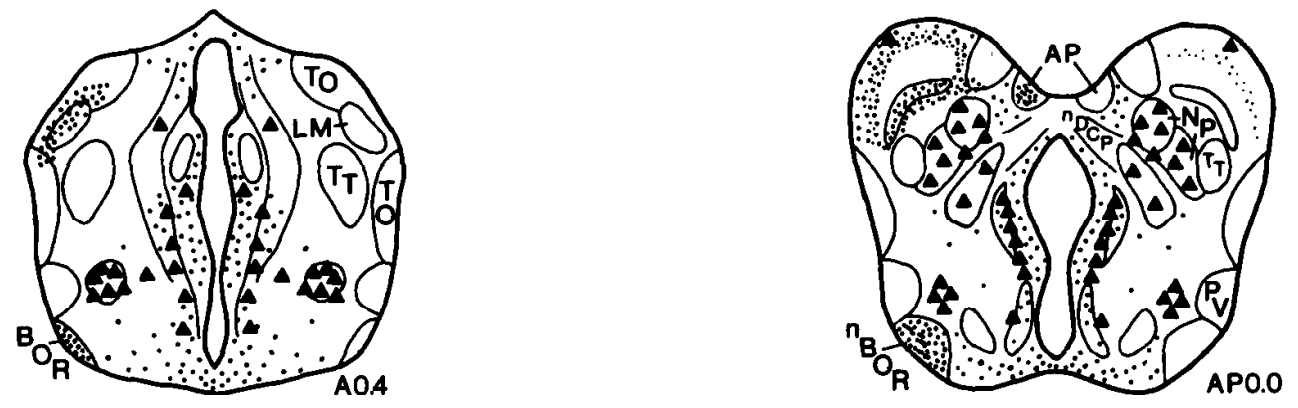

C

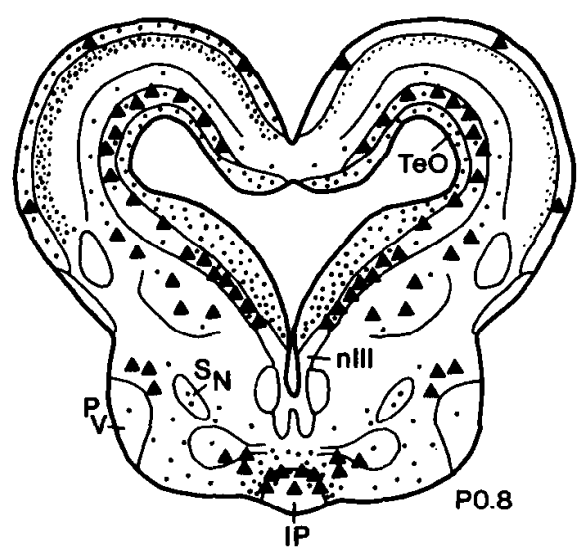

e

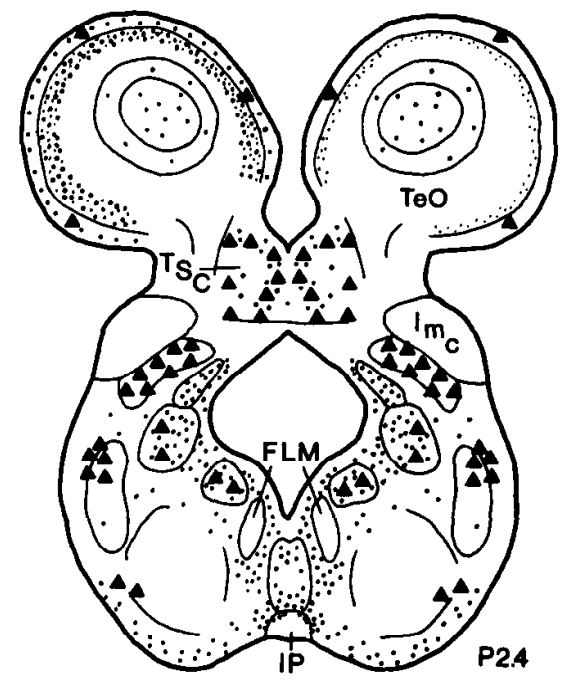

Figure 12. Same as Figure 11. See legend for details. d

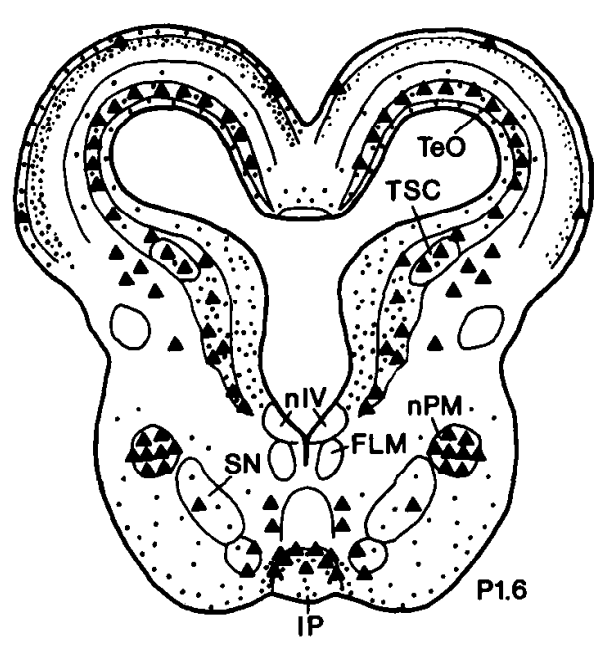

f

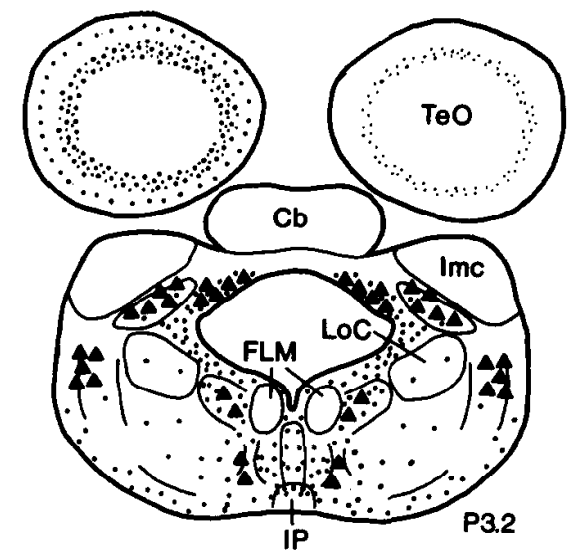



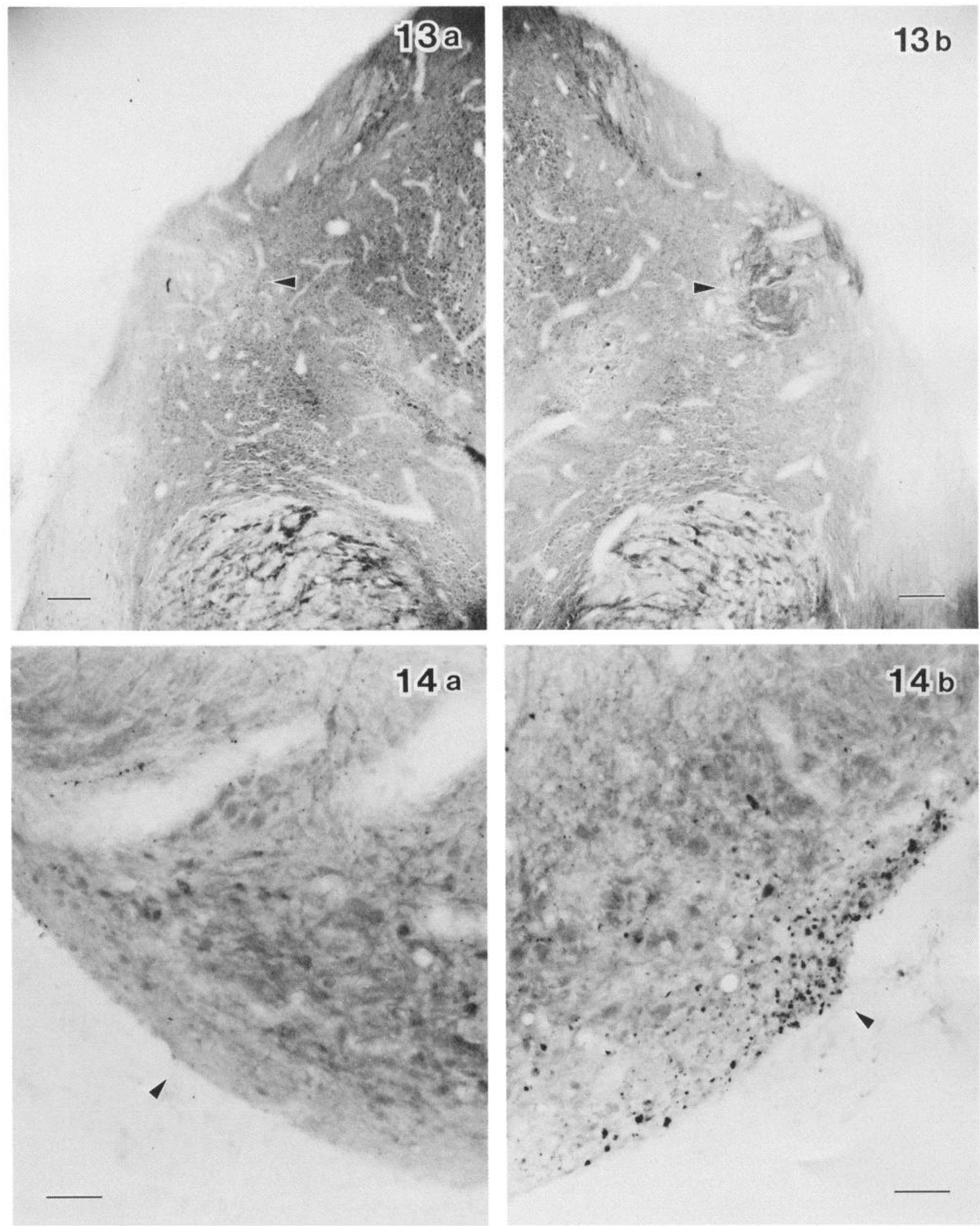

Figure 13. LANT-6-like immunoreactivity present in the dorsal lateral geniculate on the control side (b, arrowhead) is eliminated from the experimental side following enucleation and a 6 week survival time (a, arrowhead). Scale bars, $100 \mu \mathrm{m}$. Figure 14. Sections through the region of the nucleus of the basal optic root indicate that the LANT-6-like immunoreactivity present on the control side $(b$, arrowhead) is eliminated from the experimental animals which were enucleated and given a 6 week survival period (a, arrowhead). Scale bars, $50 \mu \mathrm{m}$. 

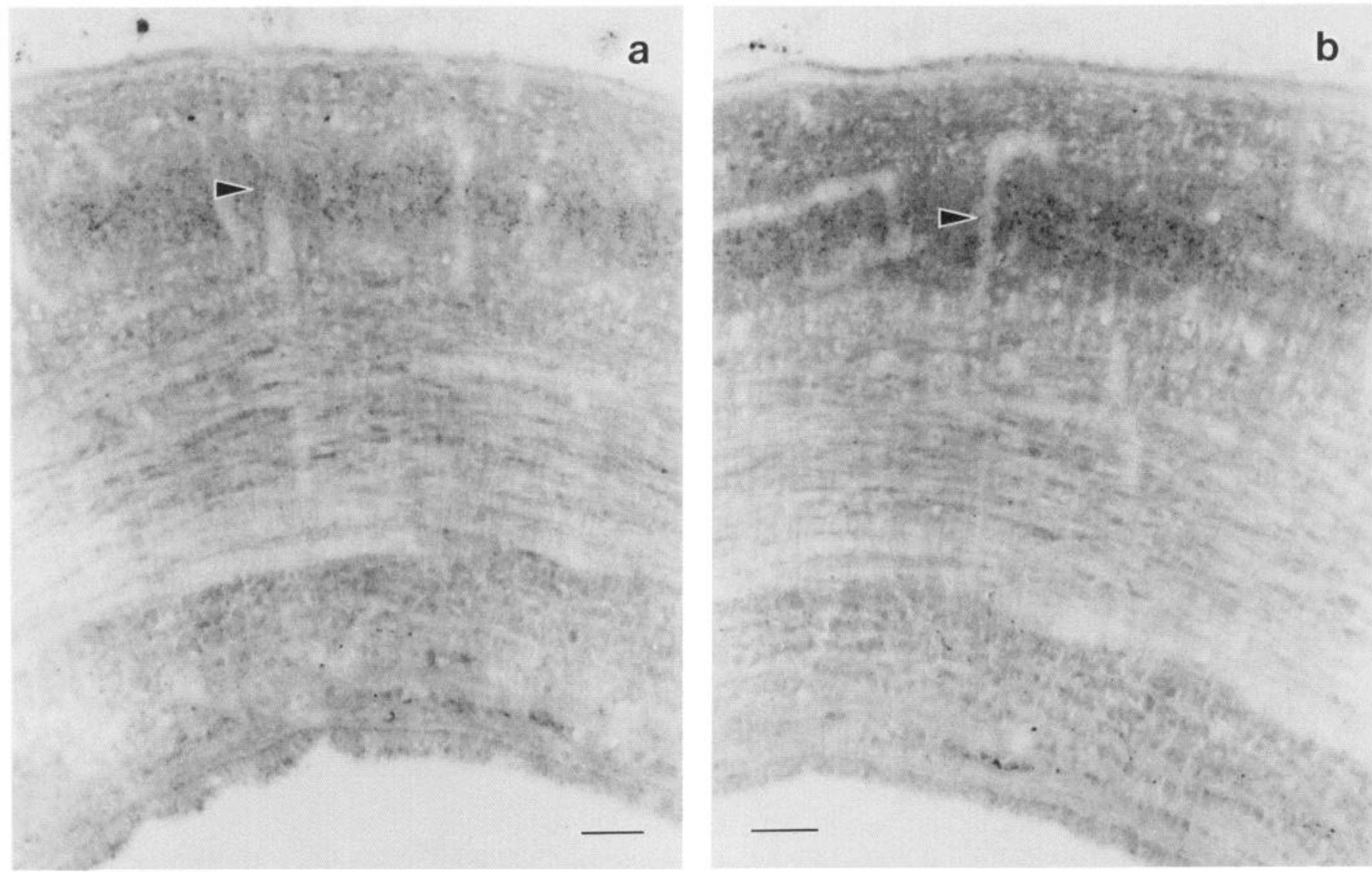

Figure 15. Following enucleation and a 6 week survival, there was a considerable depletion of LANT-6-like immunoreactivity on the experimental side $(a$, arrowhead $)$ compared with the control side $(b$, arrowhead $)$. Note that the more superficial immunoreactivity is reduced, while there was some residual immunoreactivity in deeper strata in the experimental group. Scale bars, $50 \mu \mathrm{m}$.

tides. Interestingly, an antiserum towards neuromedin $\mathrm{N}$, a mammalian variant of LANT-6 in which an isoleucine is substituted for the asparagine in the second position, cross-reacts with extracts of the turtle brain. The neuromedin $\mathrm{N}$-immunoreactive material present in this tissue was, however, shown to differ from both LANT-6 and neuromedin N (Reiner and Carraway, 1987). Thus, the additional substances observed in Figure 7 could be peptides related to the neuromedin $\mathrm{N}$-family.

The results of the enucleation experiments support the conclusion that LLI is contained within ganglion cells. It seems highly likely that degeneration of ganglion cell axons consequent to the enucleation accounts for the significant depletion of LLI on the side of the brain contralateral to the enucleated eye. Measurements by RIA confirmed that monocular enucleation did result in a reduction of LLI in the contralateral tectum compared to the ipsilateral tectum. The lack of any significant depletion of LLI in the remainder of the brain is probably due to the large amounts of LANT- 6 in the rest of the brain relative to the small amounts in the retinal recipient areas. These enucleations did not, however, have an effect on the levels of NLI in the contralateral as compared to the ipsilateral tectum. This result suggests that the reduction in LLI consequent to enucleation was a specific effect of the loss of LLI-positive retinal input fibers and was not the secondary and generalized effect of deafferentation on intrinsic peptidergic systems of the tectum.

\section{Central projections}

Our present results indicate that the retina has LLI-positive projections to all central targets of the retina in turtles. Previous studies have shown that LLI-positive cells are also present in the GCL of the retina in rats, chickens, and goldfish ( $\mathrm{Li}$ et al., 1984; Eldred et al., 1987), and prominent LLI-positive fibers are present in the retinal terminal layers of the tectum and in the nucleus of the basal optic root in pigeons and bullfrogs (Reiner, 1986, and unpublished observations). These results and the present study suggest that LANT-6 or LANT-6-related peptide(s) may be present in retinal ganglion cells and their central projections in a wide variety of vertebrate species. In few cases have neuropeptides been unequivocally localized previously to retinal ganglion cells in normal adult retinas. Recently, substance $\mathrm{P}$ has been reported within a population of ganglion cells in the rabbit retina (Johnson et al., 1986). In this case, the neurons were localized in normal adult retinas. In the frog there is evidence for the existence of neuropeptide-containing ganglion cells as well. Immunocytochemical studies in frog have shown the following: (1) Several specific types of peptidergic fibers are reduced or eliminated from retinal terminal layers of the tectum after enucleation (Kuljis and Karten, 1983), and there can be regeneration of peptide-containing retinofugal axons back into the optic tectum (Kuljis and Karten, 1985a); (2) optic nerve 


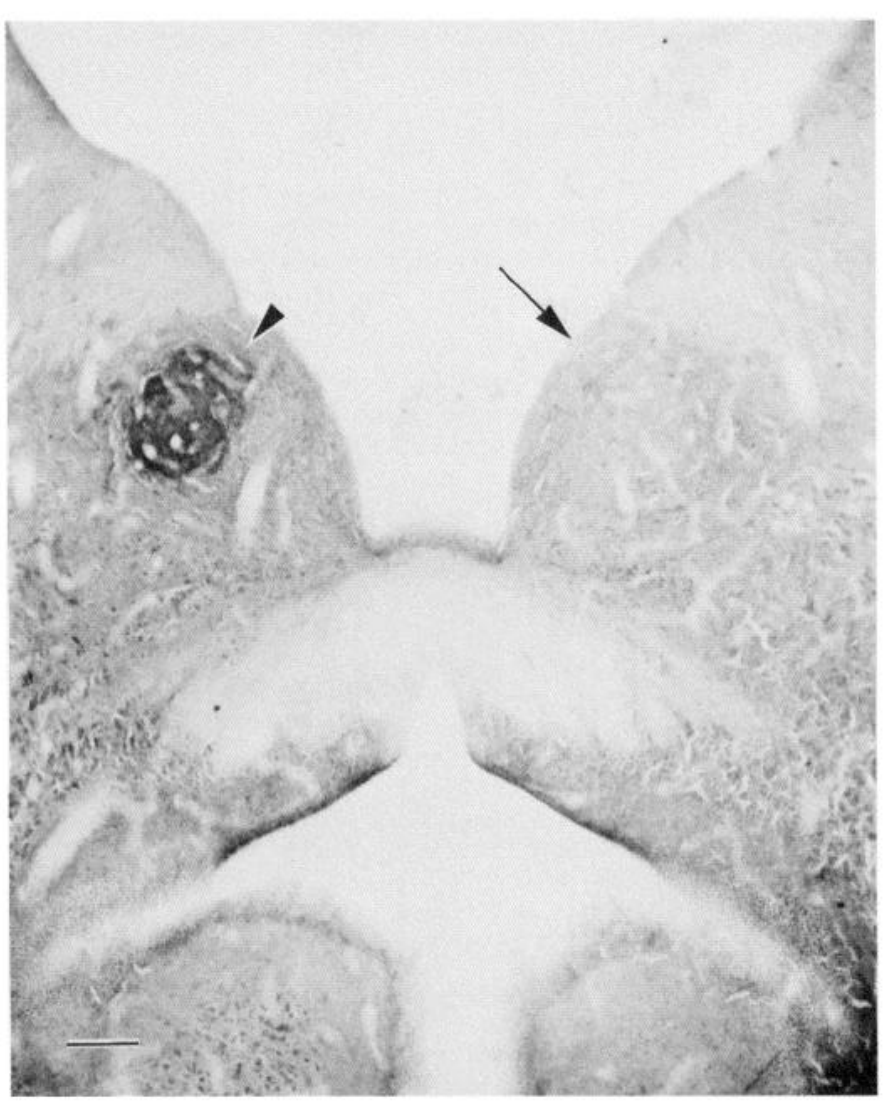

Figure 16. Section through the region of the area pretectalis showing prominent LANT-6-like immunoreactivity on the control sides (arrowhead) but almost total depletion on the experimental sides (arrow) following the degeneration of the ganglion cell axons. Scale bar, $100 \mu \mathrm{m}$.

ligations in frogs result in the accumulation of substance P-like, leucine-enkephalin-like, cholecystokinin-8-like, and bombesinlike immunoreactivities in fibers in the retinal stump of the optic nerve (Kuljis et al., 1984); and (3) finally, the presence of neuropeptides in ganglion cells can be demonstrated in developing retina, but they are not present in the adult (Kuljis and Karten, 1985b). It is important to note that although there is the previously cited evidence for the existence of peptidergic ganglion cells in frog retina, there has been no demonstration of peptidergic ganglion cells in normal adult frog retina.

In contrast, as shown in the present study, LLI is readily observed in retinal ganglion cells and the number of LLI-positive fibers in all central retinal areas can be dramatically reduced by enucleation. In light of other work (Li et al., 1984; Reiner, 1986), it seems likely, therefore, that LLI is present in retinal ganglion cells and their central projections in a variety of vertebrate groups. Since LANT - 6 has been shown to have biological activities and to be found in synaptosomes of the avian brain, it seems likely that LANT-6 is neuroactive. The present results and those available in several other vertebrate groups suggest that LLI may play a role in neurotransmission within the retina, as well as between the retina and CNS.

\section{Appendix}

Abbreviations used in figures

$A P$, area pretectalis

$B O R$, basal optic root
$\mathrm{Cb}$, cerebellum

$F L M$, fasciculus longitudinalis medialis

$G$, ganglion cell layer

$G L d$, nucleus geniculatis lateralis pars dorsalis

$H b$, nucleus habenularis

iLANT-6, immunoreactive LANT-6

$\operatorname{Imc}$, nucleus isthmi pars magnocellularis

$i N T$, immunoreactive neurotensin

$I P$, nucleus interpeduncularis

$L M$, nucleus lentiformis mesencephali

$L o C$, locus coeruleus

$M E$, median eminence

$N$, inner nuclear layer

$n B O R$, nucleus basal optic root

$n D C P$, nucleus dorsalis commissuralae posterioris

$\mathrm{NHy}$, nucleus hypophysis

$n I V$, nucleus nervi trochlearis

$N P$, nucleus pretectalis

$n P M$, nucleus profundus mesencephali

$n S O$, nucleus supraopticus

$n I I I$, nucleus nervi oculomotorius

$P$, inner plexiform layer

$P D$, peduncularis dorsalis fasciculi prosencephali lateralis

$P V$, peduncularis ventralis fasciculi prosencephali lateralis

$R$, nucleus rotundus

$S N$, substantia nigra

$\mathrm{TeO}$, tectum opticum

$T O$, tractus opticus

$T S C$, torus semicircularis

$T T$, tractus tectothalamicus

\section{References}

Adams, J. C. (1977) Technical considerations on the use of horseradish peroxidase as a neuronal marker. Neuroscience 2: 141-145.

Bass, A. H., and R. G. Northcutt (1981) Retinal recipient nuclei in the painted turtle, Chrysemys picta: An autoradiographic and HRP study. J. Comp. Neurol. 199: 97-112.

Carraway, R. E., and C. F. Ferris (1983) Isolation, biological and chemical characterization, and synthesis of a NT-related hexapeptide from chicken intestine. J. Biol. Chem. 258: 2475-2479.

Carraway, R. E., and S. E. Leeman (1976) Radioimmunoassay for neurotensin-A hypothalamic peptide. J. Biol. Chem. 251: 70357044.

Carraway, R. E., S. E. Ruane, and R. Ritsema (1983) Radioimmunoassay for $\mathrm{Lys}^{8}, \mathrm{Asn}^{9}$ neurotensin ${ }^{8-13}$ : Tissue and subcellular distribution of immunoreactivity in chickens. Peptides 4:111-116.

Carraway, R. E., S. Mitra, and C. F. Ferris (1986) Pepsin-treatment of mammalian plasma generates immunoreactive and biologically active neurotensin-related peptides in micromolar concentrations. Endocrinology 119: 1519-1526.

Ehinger, B. E. J. (1985) Retinal circuitry and clinical ophthalmology. Biol. Bull. 168: 333-349.

Eldred, W. D., and R. E. Carraway (1987) Neurocircuitry of two types of neurotensin containing amacrine cells in the turtle retina. Neuroscience 21: 603-618.

Eldred, W. D., and H. J. Karten (1983) Characterization and quantification of peptidergic amacrine cells in the turtle retina: Enkephalin, neurotensin, and glucagon. J. Comp. Neurol. 221: 371-381.

Eldred, W. D., H.-B. Li, R. E. Carraway, and J. E. Dowling (1987) Immunocytochemical localization of LANT-6-like immunoreactivity within neurons in the inner nuclear and ganglion cell layers in vertebrate retinas. Brain Res. (in press).

Johnson, D., S. Yoser, and N. Brecha (1986) Substance P-like immunoreactivity in central visual pathways of the rabbit. Anat. Rec. 214: $61 \mathrm{~A}$.

Kalivas, P. W., and R. Richardson-Carlson (1985) Neuromedin N mimics the action of neurotensin in the ventral tegmental area but not in the nucleus acumbens. Soc. Neurosci. Abstr. 11: 884 . 
Kitabgi, P., F. Checkler, and J. P. Vincent (1984) Comparison of some biological properties of neurotensin and its natural analog LANT-6. Eur. J. Pharmacol. 99: 357-360.

Kolb, H. (1982) The morphology of the bipolar cells, amacrine cells and ganglion cells in the retina of the turtle Pseudemys scripta elegans. Phil. Trans. R. Soc. London B 298: 355-393.

Kuljis, R. O., and H. J. Karten (1983) Modifications in the laminar organization of peptide-like immunoreactivity in the anuran optic tectum following retinal deafferentation. J. Comp. Neurol. 217: 239251.

Kuljis, R. O., and H. J. Karten (1985a) Regeneration of peptidecontaining retinofugal axons into the optic tectum with reappearance of a substance P-containing lamina. J. Comp. Neurol. 240: 1-15.

Kuljis, R. O., and H. J. Karten (1985b) Further evidence indicating the existence of various populations of peptide-containing retinal ganglion cells in Rana pipiens. Soc. Neurosci. Abstr. 11: 237.

Kuljis, R. O., J. E. Krause, and H. J. Karten (1984) Peptide-like immunoreactivity in anuran optic nerve fibers. J. Comp. Neurol. 226: 222-237.

Li, H.-B., W. D. Eldred, R. E. Carraway, and J. E. Dowling (1984) Localization of LANT-6-like immunoreactivity within ganglion and amacrine cells in vertebrate retina. Invest. Ophthalmol. Vis. Sci. (Suppl.) 25: 284.

Mesulam, M. M. (1981) Enzyme histochemistry of horseradish peroxidase for tracing neural connections with the light microscope. In Current Trends in Morphological Techniques, Vol. 1, pp. 1-54, CRC Press, Florida.

Minamino, N., K. Kangawa, and H. Matsuo (1984) Neuromedin N:
A novel neurotensin-like peptide identified in porcine spinal cord. Biochem. Biophys. Res. Commun. 122: 542-549.

Nemeroff, C. B., and A. J. Prange, Jr. (1982) Neurotensin, A brain and gastrointestinal peptide. Ann. NY Acad. Sci. 400: 1-368.

Peterson, E. H., and P.S. Ulinski (1979) Quantitative studies of retinal ganglion cells in a turtle, Pseudemys scripta elegans I. Number and distribution of ganglion cells. J. Comp. Neurol. 186: 17-42.

Ramon, P. (1896) Estructura del encefalo del camaeleon. Rev. Trimest. Microgr. 1: 46-82.

Ramon y Cajal, S. (1933) Die Retina der Wirbeltiere, Bergmann, Wiesbaden. (Translated by S. A. Thorpe and M. Glickstein (1972) The Structure of the Retina. Thomas, Springfield, IL.)

Reiner, A. (1981) A projection of displaced ganglion cells and giant ganglion cells to the accessory optic nuclei in turtle. Brain Res. 204: 403-409.

Reiner, A. (1986) Evidence for the presence of the neurotensin-related hexapeptide LANT-6 in ganglion cells of the pigeon. Invest. Opthalmol. Vis. Sci. (Suppl.) 27: 185.

Reiner, A., and R. E. Carraway (1985) Phylogenetic conservatism in the presence of a neurotensin-related hexapeptide in neurons of globus pallidus. Brain Res. 341: 365-371.

Reiner, A., and R. E. Carraway (1987) Immunohistochemical and biochemical studies on Lys ${ }^{8}$-Asn'-Neurotensin ${ }^{8-13}$ (LANT6)-related peptides in the basal ganglia of pigeons, turtles, and hamsters. $\mathbf{J}$. Comp. Neurol. 257: 453-467.

Weiler, R., and P. L. Marchiafava (1981) Physiological and morphological study of the inner plexiform layer in the turtle retina. Vision Res. 21 : 1635-1638. 